Sheridan College

SOURCE: Sheridan Institutional Repository

Faculty Publications and Scholarship

8-10-2005

\title{
Toll-like Receptor-4 Regulation of Hepatic Cyp3a11 Metabolism in a Mouse Model of LPS-induced CNS Inflammation
}

Kerry B. Goralski

Dalhousie University

Dalya Abdulla

Dalhousie University, dalya.abdulla@sheridancollege.ca

Christopher J. Sinal

Dalhousie University

Andre Arsenault

Dalhousie University

Kenneth W. Renton

Dalhousie University

Follow this and additional works at: https://source.sheridancollege.ca/fahcs_heal_publ

Part of the Medicinal and Pharmaceutical Chemistry Commons

\section{SOURCE Citation}

Goralski, Kerry B.; Abdulla, Dalya; Sinal, Christopher J.; Arsenault, Andre; and Renton, Kenneth W., "Toll-like Receptor-4 Regulation of Hepatic Cyp3a11 Metabolism in a Mouse Model of LPS-induced CNS Inflammation" (2005). Faculty Publications and Scholarship. 16.

https://source.sheridancollege.ca/fahcs_heal_publ/16

\section{(i) $(9$}

This work is licensed under a Creative Commons Attribution-Noncommercial-No Derivative Works 4.0 License. This Article is brought to you for free and open access by SOURCE: Sheridan Institutional Repository. It has been accepted for inclusion in Faculty Publications and Scholarship by an authorized administrator of SOURCE: Sheridan Institutional Repository. For more information, please contact source@sheridancollege.ca. 


\title{
Toll-like receptor-4 regulation of hepatic Cyp3a11 metabolism in a mouse model of LPS-induced CNS inflammation
}

\author{
Kerry B. Goralski, ${ }^{1,2}$ Dalya Abdulla, ${ }^{1}$ Christopher J. Sinal, ${ }^{1}$ Andre Arsenault, ${ }^{1}$ and Kenneth W. Renton ${ }^{1}$ \\ ${ }^{1}$ Department of Pharmacology and ${ }^{2}$ Department of Pediatrics, IWK \\ Health Centre, Dalhousie University, Halifax, Nova Scotia, Canada
}

Submitted 22 December 2004; accepted in final form 29 April 2005

\begin{abstract}
Goralski, Kerry B., Dalya Abdulla, Christopher J. Sinal, Andre Arsenault, and Kenneth W. Renton. Toll-like receptor-4 regulation of hepatic Cyp3al1 metabolism in a mouse model of LPS-induced CNS inflammation. Am J Physiol Gastrointest Liver Physiol 289: G434-G443, 2005. First published May 5, 2005; doi:10.1152/ajpgi.00562.2004.— Central nervous system (CNS) infection and inflammation severely reduce the capacity of cytochrome $P$-450 metabolism in the liver. We developed a mouse model to examine the effects of CNS inflammation on hepatic cytochrome $P-450$ metabolism. FVB, C57BL/6, and $\mathrm{C} 3 \mathrm{H} / \mathrm{HeouJ}$ mice were given Escherichia coli LPS $(2.5 \mu \mathrm{g})$ by intracerebroventricular (ICV) injection. The CNS inflammatory response was confirmed by the elevation of TNF- $\alpha$ and/or IL- $1 \beta$ proteins in the brain. In all mouse strains, LPS produced a $60-70 \%$ loss in hepatic Cyp3all expression and activity compared with saline-injected controls. Adrenalectomy did not prevent the loss in Cyp3a11 expression or activity, thereby precluding the involvement of the hypothalamic-adrenal-pituitary axis. Endotoxin was detectable $(1-10 \mathrm{ng} / \mathrm{ml})$ in serum between 15 and $120 \mathrm{~min}$ after ICV dosing of $2.5 \mu \mathrm{g}$ LPS. Peripheral administration of $2.5 \mu \mathrm{g}$ LPS by intraperitoneal injection produced similar serum endotoxin levels and a similar loss $(60 \%)$ in Cyp3a11 expression and activity in the liver. The loss of Cyp3a11 in response to centrally or peripherally administered LPS could not be evoked in Toll-like receptor-4 (TLR4)-mutant $(\mathrm{C} 3 \mathrm{H} /$ $\mathrm{HeJ}$ ) mice, indicating that TLR4 signaling pathways are directly involved in the enzyme loss. In summary, we conclude that LPS is transferred from the brain to the circulation in significant quantities in a model of CNS infection or inflammation. Subsequently, LPS that has reached the circulation stimulates a TLR4-dependent mechanism in the periphery, evoking a reduction in Cyp3a11 expression and metabolism in the liver.
\end{abstract}

lipopolysaccharide; cytochrome P-450; drug metabolism

THE CYTOCHROMES $P-450$ are a gene superfamily of hemecontaining enzymes that contribute to the metabolism and elimination of exogenous and endogenous substances $(1,5)$. The highest amounts of drug-metabolizing cytochromes $P-450$ are found in the liver and intestine, with lower amounts found in other organs, including the kidney, lung, and brain. In rodents and humans, enzymes of the CYP3A subfamily comprise the majority of cytochrome $P-450$ in the liver $(30-50 \%)$ and metabolize $50-60 \%$ of clinically used drugs (1).

It is well known that cytochromes $P-450$ are modulated during inflammatory responses and/or infectious diseases (28, 39). In general, acute systemic inflammatory responses trigger reductions in hepatic cytochrome $P-450$ enzyme expression and activity, with the consequence of reduced drug metabolism during episodes of inflammation. Bacterial LPS is the major

Address for reprint requests and other correspondence: K. W. Renton, Dept. of Pharmacology, Dalhousie Univ., Rm. 5C Sir Charles Tupper Bldg., 5850 College St., Halifax, Nova Scotia, Canada B3H 1X5 (e-mail: Ken. Renton@dal.ca). stimulus for inflammatory responses in the central nervous system (CNS) caused by gram-negative meningeal pathogens (42). Inflammatory responses in the brain caused by the administration of Escherichia coli LPS into the lateral ventricle of rats reduce hepatic CYP1A1/2, CYP2B1/2, CYP2D1, CYP2E1, and CYP3A1/2 enzyme activities and/or protein levels $(14,27,31,40,41,45)$. The signaling mechanisms that produce peripheral responses during CNS infection have been proposed to include peripheral inflammatory cytokines, the hypothalamic-adrenal-pituitary (HPA) axis, the sympathetic nervous system, and reactive oxygen species $(8,15,48)$. Because of the complex nature of these signaling mechanisms, it has been difficult to determine which pathways are most important for the loss in hepatic drug metabolism in vivo. Mice with disruptions of genes contributing to inflammatory signaling pathways (TNF- $\alpha$ receptor, IL-6, signal transducer and activator of transcription-1, and nitric oxide synthase-2-null mice) have been used as a tool to delineate the factors that are important for decreasing hepatic drug metabolism during peripheral inflammatory responses $(32,43,46,50)$. The availability of mice with genetic alterations in immune signaling pathways will allow a more precise mechanistic examination of the biochemical links between CNS infection and inflammation and drug metabolism and disposition in vivo.

Toll-like receptor-4 (TLR4) has been identified as the transmembrane receptor that specifically recognizes LPS and initiates intracellular signal transduction and an immune response to that bacterial cell wall component $(6,36)$. LPS signaling during conditions of systemic inflammation involves the binding of LPS to the serum protein LPS binding protein, followed by association with CD14, a receptor found either in the membrane or in soluble form. The complex is then thought to translocate to TLR4 to initiate intracellular signal transduction pathways, including NF- $\mathrm{BB}$ activation and inflammatory cytokine production $(4,6)$. A similar process occurs in the regions of the brain (choroid plexus, leptomeninges, and circumventricular organs) that coexpress the CD14 and TLR4 components of the LPS signal transduction pathway $(20,30)$. Despite the importance of TLR4 in LPS signaling, it has received minimal attention with regard to regulation of drug metabolism by inflammatory processes. $\mathrm{C} 3 \mathrm{H} / \mathrm{HeJ}$ mice contain a single point mutation at amino acid 712 that renders TLR4 ineffective and the mice unresponsive to stimulation by LPS $(36,37)$. Thus the $\mathrm{C} 3 \mathrm{H} / \mathrm{HeJ}$ mouse strain represents a useful model to examine whether changes in hepatic cytochrome $P$ - 450 expression during LPS exposure can be specifically attributed to activation of TLR4 signaling pathways.

\footnotetext{
The costs of publication of this article were defrayed in part by the payment of page charges. The article must therefore be hereby marked "advertisement" in accordance with 18 U.S.C. Section 1734 solely to indicate this fact.
} 
The aim of this study was to examine the signaling mechanisms responsible for the loss in hepatic cytochrome $P-4503 \mathrm{~A}$ in a model of gram-negative bacterial infection or inflammation of the mouse brain. Our novel findings indicated that, in this experimental model, the flux of LPS from brain to blood and the activation of a peripheral TLR4-mediated immune response lead to a reduction Cyp3al1 drug metabolism in the liver.

\section{MATERIALS AND METHODS}

Mice and production of CNS inflammation. FVB and C57BL/6 mouse strains were used initially in the study to develop methodology and to characterize the effects of CNS infection or inflammation on mouse cytochrome $P-450$ metabolism. Subsequently, the $\mathrm{C} 3 \mathrm{H} / \mathrm{HeJ}$ and closely related $\mathrm{C} 3 \mathrm{H} / \mathrm{HeouJ}$ strains were used to specifically address the role of TLR4 in mediating changes in hepatic cytochrome $P-450$ expression and activity. Adult male mice (FVB strain) and adrenalectomized FVB mice were obtained from Taconic Laboratories (Germantown, NY). Male mice (6-8 wk old) containing either a spontaneous mutation in TLR4 gene $(\mathrm{C} 3 \mathrm{H} / \mathrm{HeJ})$ and age-matched LPS-responsive $(\mathrm{C} 3 \mathrm{H} / \mathrm{HeouJ})$ mice were obtained from The Jackson Laboratory (Bar Harbor, ME). C57BL/6 mice were obtained from our in-house breeding colony. The mice were housed in cages lined with corncob bedding and had free access to water and Purina mouse chow. Drinking water for adrenalectomized mice was supplemented with 5\% glucose. Mice were kept on a 12:12-h day-night cycle and were allowed to acclimatize in the animal holding facilities for a period of $1 \mathrm{wk}$ before experimentation. The Dalhousie University Committee on Laboratory Animals approved all experimental procedures involving mice according to guidelines of the Canadian Council on Animal Care.

On the day of the experiments, mice were anesthetized with enflurane $(3.0-4.0 \%)$ and were given an infusion of either endotoxinfree saline $(2.5 \mu \mathrm{l})$ or gel-purified $E$. coli LPS (serotype 0127:B8; 2.5 $\mu \mathrm{g}$ in $2.5 \mu \mathrm{l}$ ) into the lateral cerebral ventricle [intracerebroventricular (ICV)] using a Harvard Apparatus syringe pump. The solutions were injected at a rate of $2.5 \mu \mathrm{l} / \mathrm{min}$. The coordinates for the sterotaxic injections were $-2.5 \mathrm{~mm}$ dorsal/ventral, $-1.5 \mathrm{~mm}$ lateral, and -0.2 $\mathrm{mm}$ anterior/posterior from the bregma (11).

For the intraperitoneal experiments, mice were injected intraperitoneally with either a low $(2.5 \mu \mathrm{g})$ or high $(125 \mu \mathrm{g})$ dose of purified E. coli LPS suspended in $100 \mu$ l of $0.9 \%$ endotoxin-free saline. Control mice were injected with $100 \mu \mathrm{l}$ of the saline vehicle.

Phenol-extracted LPS, but not the gel-purified LPS, contains micromolar levels of biologically active contaminants, including glutamate and adenosine (16), which could precipitate nonspecific responses in our model. For those reasons, chromatographically purified LPS is the preferred preparation for in vivo studies of this nature. To assess blood-brain barrier permeability changes, a tracer amount (4 nmol) of D-[1- $\left.{ }^{14} \mathrm{C}\right]$ mannitol was administered peripherally to control mice and to mice $0,1,4$, and $24 \mathrm{~h}$ after $2.5 \mu \mathrm{g}$ LPS was administered into the lateral ventricle. Brain levels of total radioactivity were measured by scintillation counting $1 \mathrm{~h}$ after the $\left[{ }^{14} \mathrm{C}\right]$ mannitol injection. For the TNF- $\alpha$ experiment, $50 \mathrm{ng}$ of recombinant mouse TNF- $\alpha$ (R\&D systems) or vehicle containing sterile filtered PBS and $0.1 \%$ BSA were administered into the lateral ventricle in a total volume of $2.5 \mu \mathrm{l}$.

Tissue and microsome preparation. Mice were killed 4 or $24 \mathrm{~h}$ after the ICV administration of either LPS or saline, at which point liver and brain samples were obtained. The whole brain was homogenized in $1.5 \mathrm{ml}$ of PBS (pH 7.4) and spun at 13,000 rpm for $10 \mathrm{~min}$. Brain supernatants were stored at $-80^{\circ} \mathrm{C}$ until utilized for cytokine measurements. Samples (100 mg) were obtained from the liver and frozen in liquid nitrogen for total RNA isolations. The remaining liver was removed and used to prepare microsomes according to previously published methods (10). We homogenized liver tissue in ice-cold $1.15 \% \mathrm{KCl}$ for $15-20 \mathrm{~s}$ using a Polytron homogenizer. The homog- enates were centrifuged at $10,000 \mathrm{~g}$ for $10 \mathrm{~min}$ at $4^{\circ} \mathrm{C}$, and the supernatants were recentrifuged at $110,000 \mathrm{~g}$ for $40 \mathrm{~min}$. The resulting microsomal pellets were resuspended in $0.8 \mathrm{ml}$ of glycerol buffer $(\mathrm{pH}$ 7.5) that contained $50 \mathrm{mM} \mathrm{KH}_{2} \mathrm{PO}_{4}, 20 \%$ glycerol, and $0.40 \% \mathrm{KCl}$. Samples were stored at $-80^{\circ} \mathrm{C}$ until enzymatic assays were performed. Microsomal protein content was determined by the method of Lowry et al. (23) using BSA as a standard.

Cyp3all enzyme assays. The formation of $\alpha$-hydroxytriazolam from triazolam was used as a specific indicator for mouse Cyp3all activity (34). Incubation mixtures (performed in duplicate) contained $500 \mu \mathrm{g}$ of total microsomal protein, $20 \mu \mathrm{M}$ triazolam, and $1 \mathrm{mM}$ NADPH in $100 \mathrm{mM}$ PBS (pH 7.4). The reaction mixtures (1 ml final volume) were incubated in a $37^{\circ} \mathrm{C}$ water bath with a shaker set at 100 oscillations/min. After $15 \mathrm{~min}$, the reactions were stopped by the addition of $5 \mathrm{ml}$ of dichloromethane; 2,000 ng of phenacetin were added to each sample as an internal standard. The samples were then centrifuged at 2,700 rpm for a period of $10 \mathrm{~min}$, and the lower organic phase containing the metabolites and internal standard was transferred into a clean glass tube and evaporated to dryness using a nitrogen evaporator followed by reconstitution in $200 \mu \mathrm{l}$ of HPLC mobile phase. The HPLC mobile phase consisted of acetonitrile [20\% ( $\mathrm{vol} /$ vol)] and methanol [35\% ( vol/vol)] in $0.01 \mathrm{M}$ potassium phosphate buffer ( $45 \% \mathrm{vol} / \mathrm{vol}$ ) buffered to $\mathrm{pH} 7.4$ with $\mathrm{NaOH}$. Reconstituted samples $(50 \mu \mathrm{l})$ were separated on a reverse-phase C-8 $(25 \mathrm{~cm} \times 4.5$ $\mathrm{mm}$ inner diameter) analytical column (Beckman Coulter, Fullerton, CA) attached to a Waters 2690 separation module. The mobile phase flow rate for separations was set at $1.0 \mathrm{ml} / \mathrm{min}$. The approximate retention times were $5.0 \mathrm{~min}$ for $\alpha$-hydroxytriazolam, $8.0 \mathrm{~min}$ for phenacetin, and $12.0 \mathrm{~min}$ for triazolam; these were detected by UV absorption at $220 \mathrm{~nm}$ (Waters 2487 Dual $\lambda$ absorption unit).

RNA isolation and Northern analyses. Total liver RNA was isolated using TRIzol reagent (Invitrogen, Carlsbad, CA) according to the manufacturer's instructions. Quality of the RNA was determined spectrally by measuring the 260 -to-280-nm absorbance ratio and was typically between 1.8 and 2.0. For Northern blot analyses, $10 \mu \mathrm{g}$ of total RNA were resolved on a $1.1 \%$ agarose-formaldehyde denaturing gel. RNA was transferred overnight to a nylon membrane (Immobilon $\mathrm{NY}^{+}$; Millipore, Bedford, MA) and was fixed to the membrane by UV cross-linking and heating for $1 \mathrm{~h}$ at $65^{\circ} \mathrm{C}$. $\left[{ }^{32} \mathrm{P}\right] \mathrm{CTP}$ probes for mouse Cyp3all and Gapdh mRNA were generated from the corresponding cDNAs using the RmT Random Primer labeling kit according to manufacturer's instructions (Stratagene). Blots were prehybridized for $1 \mathrm{~h}$ at $65^{\circ} \mathrm{C}$ in $10 \mathrm{ml}$ of Sigma Perfecthyb Plus (Sigma, St. Louis, MO) followed by overnight hybridization with $\left[{ }^{32} \mathrm{P}\right] \mathrm{CTP}$ probes. Blots were exposed to storage phosphor screen (Amersham Biosciences, Piscataway, NJ) for 16-24 h and scanned with a phosphor imager (Amersham Biosciences). Quantification was performed using ImageQuant 5.2 software (Amersham Biosciences).

Quantitative real-time PCR. Total RNA $(5 \mu \mathrm{g})$ was reverse transcribed using Stratascript reverse transcriptase (Stratagene, Cedar Creek, TX) with $12.5 \mathrm{ng} / \mu \mathrm{l}$ random hexamers $\mathrm{pd}(\mathrm{N})_{6}$ and $1.0 \mathrm{mM}$ dNTPs according to the supplier's instructions. We amplified cDNA product $(1 \mu \mathrm{l})$ by quantitative PCR using $125 \mathrm{nM}$ gene-specific primers in a total volume of $20 \mu \mathrm{l}$ with brilliant SYBR green QPCR Master Mix using the Stratagene MX3000p thermocycler. For TNF- $\alpha$, a 61-bp product was generated with the forward 5'-CCC TCA CAC TCA GAT CAT CTT CT-3' and reverse 5'-GCT ACG ACG TGG GCT ACA G-3' primers (GenBank accession no. NM_013693). For GAPDH, a 245-bp amplicon was generated with the forward 5'-AAG GTC GGT GTG AAC GGA TTT GG-3' and reverse 5'-TTG ATG TTA GTG GGG TCT CGC TCC-3' primers (GenBank accession no. NM_008084). The amplification protocol consisted of a 10-min hot start at $94^{\circ} \mathrm{C}$, followed by 40 cycles of denaturation at $94^{\circ} \mathrm{C}$ for $15 \mathrm{~s}$, annealing at $60^{\circ} \mathrm{C}$ for $18 \mathrm{~s}$, and elongation at $72^{\circ} \mathrm{C}$ for $30 \mathrm{~s}$. Melting curves followed by separation of PCR products on a $2.5 \%$ agarose gel were used to ensure the formation of a single product at the appropriate size. The threshold cycle values for TNF- $\alpha$ and control gene 
Gapdh were obtained with a threshold of 3 SD above background. Relative TNF- $\alpha$ expression normalized to Gapdh was calculated using the $\Delta \Delta \mathrm{C}_{\mathrm{T}}$ (where $\mathrm{C}_{\mathrm{T}}$ is threshold cycle) method (see Ref. 22).

Cytokine measurements. We measured the levels of TNF- $\alpha$ and IL-1 $\beta$ in brain homogenates and serum 2 or $4 \mathrm{~h}$ after LPS administration ICV using a murine sandwich ELISA prepared as previously described (26). The results are expressed as nanograms of cytokine per gram of brain wet weight or nanograms of cytokine per milliliter of serum.

Serum LPS measurements. LPS $(2.5 \mu \mathrm{g})$ was administered by the ICV or intraperitoneal route to endotoxin-responsive $\mathrm{C} 3 \mathrm{H} / \mathrm{HeouJ}$ mice. Mice were killed $15 \mathrm{~min}, 30 \mathrm{~min}, 2 \mathrm{~h}$, or $24 \mathrm{~h}$ later, and trunk blood was collected. All groups were compared with noninjected control mice. We measured serum LPS levels using the kinetic chromogenic Limulus amebocyte lysate assay as per the manufacturer's instructions (Associates of Cape Cod, Cape Cod, MA). The assay was linear from $0.395 \mathrm{pg} / \mathrm{ml}$ to $100 \mathrm{ng} / \mathrm{ml}$ LPS. We calculated the area under the curve $\left(\mathrm{AUC}_{0.25-2 \mathrm{~h}}\right)$ from the mean serum LPS concentrations using the trapezoidal method.

Data analyses. Data are expressed as means \pm SE of three or four separate animals. An unpaired $t$-test was used to compare means between two groups. ANOVA was used for multiple-comparison procedures. A Tukey's test was used for post hoc analysis of the significant ANOVA. A difference in mean values with a value of $P \leq$ 0.05 was considered to be significant.

Chemicals. Purified E. coli LPS (serotype 0127:B8), phenacetin, $\alpha$-hydroxytriazolam, ethoxyresorufin, resorufin, NADPH, and dichloromethane were obtained from Sigma. $\left[{ }^{32} \mathrm{P}\right] \mathrm{dCTP}$ was obtained from Perkin-Elmer (Boston, MA). Triazolam was obtained from Roche Pharmaceuticals. All other reagents were of the finest grade available and were purchased from commercial suppliers.

\section{RESULTS}

Administration of LPS into the lateral ventricle reduces hepatic Cyp3all expression and activity. The initial experiments carried out in the two mouse strains (FVB and C57BL/6) were required to develop a mouse model of CNS infection and inflammation and to determine whether this model exhibited reductions in Cyp3al1 expression and activity. The dose of LPS was based on previous studies that demonstrated that 0.1 $\mu \mathrm{g} / \mathrm{kg}$ LPS administered ICV was required for significant downregulation of hepatic cytochrome $P-450$ enzymes in rats $(14,31,41)$. The expression of Cyp3all and Gapdh mRNA was measured in the liver by Northern blot analyses 4 and $24 \mathrm{~h}$ after the administration of $E$. coli LPS into the left lateral cerebral ventricle (Fig. 1A). Cyp3al1 mRNA was unchanged at $4 \mathrm{~h}$ and was decreased by $60 \% 24 \mathrm{~h}$ after LPS treatment compared with the respective saline controls (Fig. 1, $B$ and $D$ ). Liver Gapdh expression was not altered by LPS treatment. Consistent with mRNA expression, the rate of $\alpha$-hydroxylation of triazolam (Cyp3al1 activity) was unchanged at $4 \mathrm{~h}$ but was decreased by $60 \%$ at $24 \mathrm{~h}$ by LPS treatment compared with the respective saline control (Fig. 1, $C$ and E). LPS (2.5 $\mu g$ ) administered ICV to $\mathrm{C} 57 \mathrm{BL} / 6$ mice produced a similar reduction in Cyp3al1 mRNA (80\%) and $\alpha$-hydroxylation of triazolam $(60 \%)$ and indicated that the effect of LPS was not restricted to the FVB strain of mice (Fig. 2).

Administration of LPS into the lateral cerebral ventricle produces CNS inflammation. Two hours after LPS was administered into the lateral ventricle of FVB mice, TNF- $\alpha$ and Il-1 $\beta$ levels were significantly increased (2-fold) compared with the saline controls (Fig. 3, $A$ and $B$ ). The increased level of TNF- $\alpha$ and Il-1 $\beta$ are consistent with the production of CNS inflam-
A

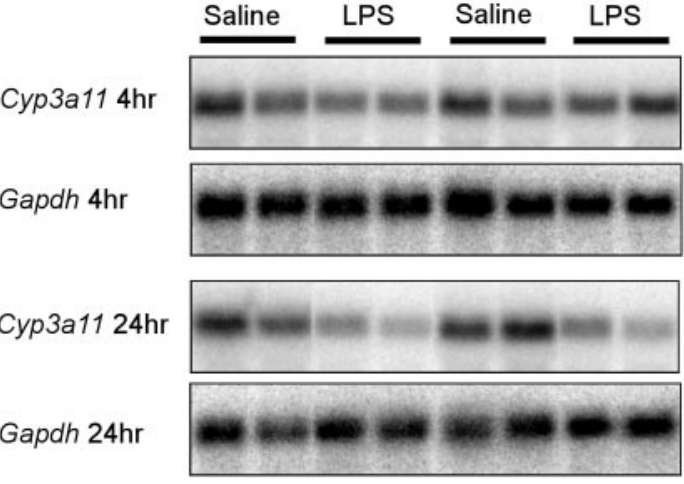

B

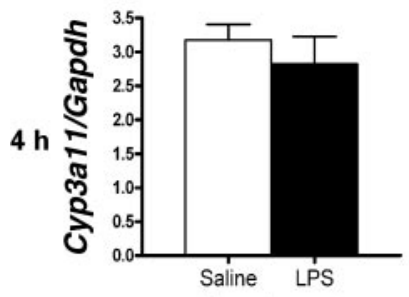

Treatment

D
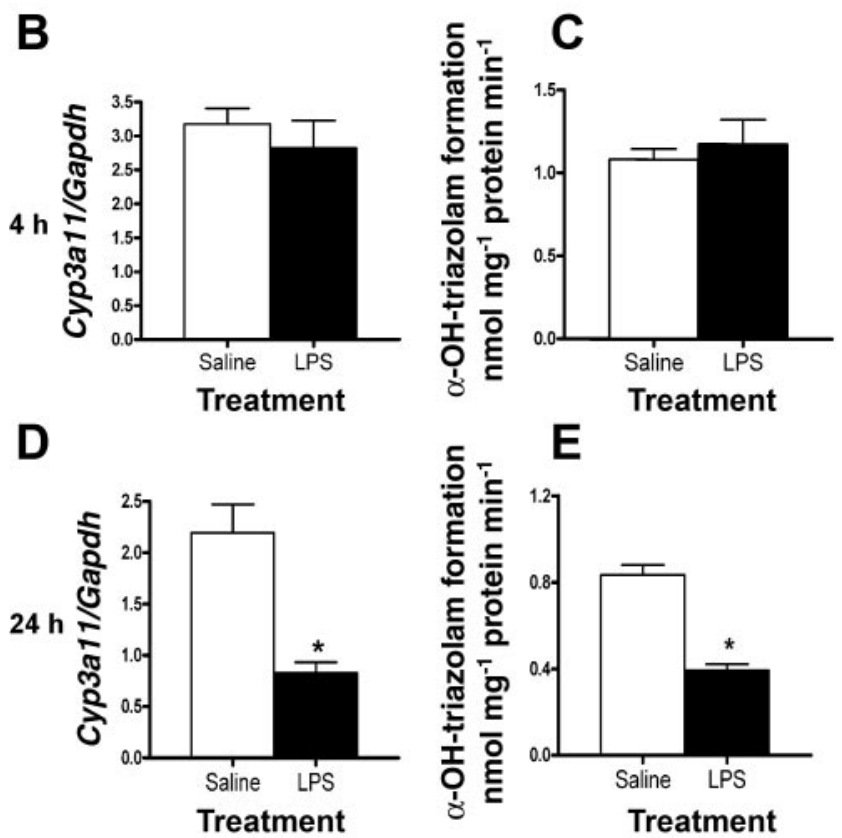

Fig. 1. Hepatic Cyp3a11 mRNA and activity were downregulated $24 \mathrm{~h}$ after intracerebroventricular (ICV) administration of LPS $(2.5 \mu \mathrm{g})$ to male FVB mice. A: representative Northern blots of Cyp3a11 and Gapdh at 4 and $24 \mathrm{~h}$ after ICV administration of LPS or saline. Band intensities were determined by densitometry, and hepatic Cyp3a11 ( $B$ and $D)$ mRNA was normalized to Gapdh mRNA. Cyp3all activity was measured $4 \mathrm{~h}(C)$ and $24 \mathrm{~h}(E)$ after LPS or saline administration by monitoring the formation of $\alpha$-hydroxytriazolam $(\alpha-\mathrm{OH}$-triazolam $)$ from triazolam in liver microsomal fractions. Each bar represents the mean $\pm \mathrm{SE}$ of 4 mice. ${ }^{*}$ Cyp 3 all mRNA and activity were lower compared with the respective saline-treated mice $(P<0.05$, unpaired $t$-test).

mation in response to LPS. A parallel increase (2-fold) in TNF- $\alpha$ and IL-1 $\beta$ in serum indicated a systemic response to ICV administered LPS (Fig. 3, $C$ and $D$ ).

HPA axis does not mediate hepatic Cyp3all downregulation following ICV administration of LPS. The release of inflammatory cytokines after LPS injection into the brain is known to activate the HPA axis and increase circulating corticosteroids, which can affect the acute phase response and gene transcription in the liver $(2,9,48)$. Thus it was important to determine the relevance of the HPA axis in contributing to the downregulation of Cyp3al1 mRNA and enzyme activity in our model (Fig. 4). Adrenalectomized and control FVB mice were left untreated or were injected with $2.5 \mu \mathrm{g}$ or LPS or saline ICV. LPS reduced Cyp3al1 expression and activity to the same degree $(70 \%)$ in both control and adrenalectomized 
A

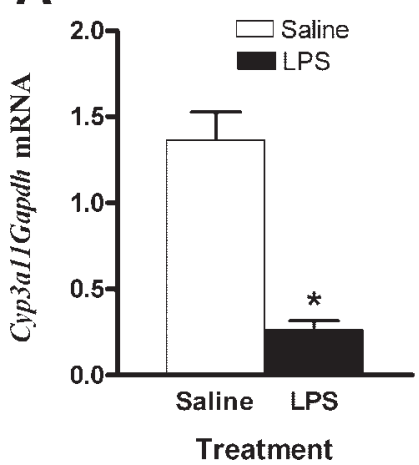

B

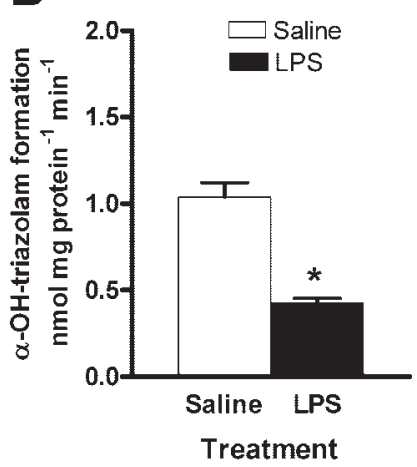

Fig. 2. Hepatic Cyp3all mRNA and activity were downregulated $24 \mathrm{~h}$ after ICV administration of LPS $(2.5 \mu \mathrm{g})$ to male C57BL/6 mice. A: hepatic Cyp3a11 mRNA expression normalized to Gapdh expression as determined by Northern blot analysis. Band intensities were determined by densitometry. Cyp3a11 activity was measured by monitoring the formation of $\alpha-\mathrm{OH}$-triazolam from triazolam in liver microsomal fractions $(B)$. Each bar represents the mean \pm SE of 4 mice. ${ }^{*} P<0.05$ compared with the respective saline-treated mice (unpaired $t$-test).

mice (Fig. 4, $A-C$ ). In control mice and adrenalectomized mice, saline administration had no effect on hepatic Cyp3all mRNA or triazolam metabolism compared with the respective untreated animals. Similarly, basal Cyp3a11 expression and triazolam hydroxylation in adrenalectomized mice was not significantly different from controls. ICV LPS in control mice significantly increased serum corticosterone compared with saline-treated or untreated control mice, indicating activation of the HPA axis (Fig. $4 D$ ). Adrenalectomy completely prevented the elevation in serum corticosterone after ICV administration of LPS.

TLR4 signaling regulates hepatic Cyp3all expression. TLR4-expressing $(\mathrm{C} 3 \mathrm{H} / \mathrm{HeouJ})$ and TLR4 mutant $(\mathrm{C} 3 \mathrm{H} / \mathrm{HeJ})$ mice were utilized to determine whether the downregulation of hepatic Cyp3a11 by LPS was mediated through stimulation of the TLR4. Twenty-four hours after LPS $(2.5 \mu \mathrm{g})$ administration to $\mathrm{C} 3 \mathrm{H} / \mathrm{HeouJ}$ mice, Cyp3all mRNA was decreased by $70 \%$ compared with the saline control (Fig. 5, $A$ and $B$ ). In sharp contrast, no loss in Cyp3all mRNA was evoked $24 \mathrm{~h}$ after LPS was administered directly into the lateral cerebral ventricle of TLR4 mutant (C3H/HeJ) mice. Liver Gapdh expression was similar in both mouse strains and was not altered by LPS treatment. Correspondingly, triazolam metabolism to $\alpha$-hydroxytriazolam was reduced by $60 \%$ in the $\mathrm{C} 3 \mathrm{H} / \mathrm{HeouJ}$ (wild-type) mice but was unchanged in the $\mathrm{C} 3 \mathrm{H} / \mathrm{HeJ}$ (TLR4 mutant) mice compared with the respective saline controls (Fig. 5C). Basal Cyp3all mRNA and triazolam hydroxylation were $40 \%$ lower in saline-treated $\mathrm{C} 3 \mathrm{H} / \mathrm{HeJ}$ vs. $\mathrm{C} 3 \mathrm{H} / \mathrm{HeouJ}$ mice. After $4 \mathrm{~h}$, LPS increased brain TNF- $\alpha$ protein in the $\mathrm{C} 3 \mathrm{H} / \mathrm{HeouJ}$ mice but not in the $\mathrm{C} 3 \mathrm{H} / \mathrm{HeJ}$ mice compared with the respective saline controls (Fig. $5 D$ ). Liver TNF- $\alpha$ mRNA expression was increased 60 -fold in the $\mathrm{C} 3 \mathrm{H} / \mathrm{HeouJ}$ mice but only 5 -fold in the $\mathrm{C} 3 \mathrm{H} / \mathrm{HeJ}$ mice $4 \mathrm{~h}$ after LPS treatment compared with the respective saline controls (Fig. 5E). These results demonstrate an inhibition of the brain and liver inflammatory responses to LPS in the TLR4-mutant $\mathrm{C} 3 \mathrm{H} / \mathrm{HeJ}$ mice and indicate that the reduction in hepatic Cyp3all expression and activity are linked to stimulation of TLR4 by LPS. Recombinant TNF- $\alpha$ (50 ng) administered ICV to the $\mathrm{C} 3 \mathrm{H} / \mathrm{HeouJ}$ and $\mathrm{C} 3 \mathrm{H} / \mathrm{HeJ}$ mice did not produce a loss in Cyp3all expression in either mouse strain $24 \mathrm{~h}$ after they were dosed (Fig. $5 F$ ).

The dose of TNF- $\alpha$ was chosen to approximate the TNF- $\alpha$ level detected in the brain 2-4 h after the LPS dose.

$L P S$ is rapidly transferred from the CNS to the periphery after administration into the lateral cerebral ventricle. During CNS infection, the leakage of endotoxin into the periphery could play a role in reducing hepatic cytochrome $P-450$ metabolism; however, the systemic distribution of LPS after its administration ICV has not been previously characterized. LPS $(2.5 \mu \mathrm{g})$ administered by the ICV route was detected in the serum $(1,000-10,000 \mathrm{pg} / \mathrm{ml}$ range) between $15 \mathrm{~min}$ and $2 \mathrm{~h}$ after mice were dosed. LPS was not detectable in the serum $24 \mathrm{~h}$ after ICV administration or in untreated control mice (Fig. $6 A$ ). When $2.5 \mu \mathrm{g}$ of LPS were administered via the intraperitoneal route, the levels of endotoxin detected were very similar to those obtained after administration of LPS by the ICV route (Fig. 6B). The intraperitoneal administration of $2.5 \mu \mathrm{g}$ LPS also produced a $60 \%$ reduction in hepatic Cyp3all mRNA and triazolam metabolism (Fig. 6, $C-E$ ). The $\mathrm{AUC}_{0.25-2}$ h results calculated for the serum LPS data were 11,817 and 8,847 $\mathrm{pg} \cdot \mathrm{ml}^{-1} \cdot \mathrm{h}^{-1}$ after ICV and intraperitoneal injection of LPS, respectively. This result directly supports the idea that a peripheral inflammatory response produced by LPS reaching the circulation after ICV injection is sufficient to produce reductions in hepatic cytochrome $P-450$ metabolism. The uptake of peripherally administered $\left[{ }^{14} \mathrm{C}\right]$ mannitol was used as a marker of changes in blood-brain permeability induced by ICV administration of LPS (Fig. 6F). Increased blood-brain permeability was suggested by the significant increase in total brain $\left[{ }^{14} \mathrm{C}\right]$ mannitol 5 and $24 \mathrm{~h}$ after LPS administration compared with control mice.
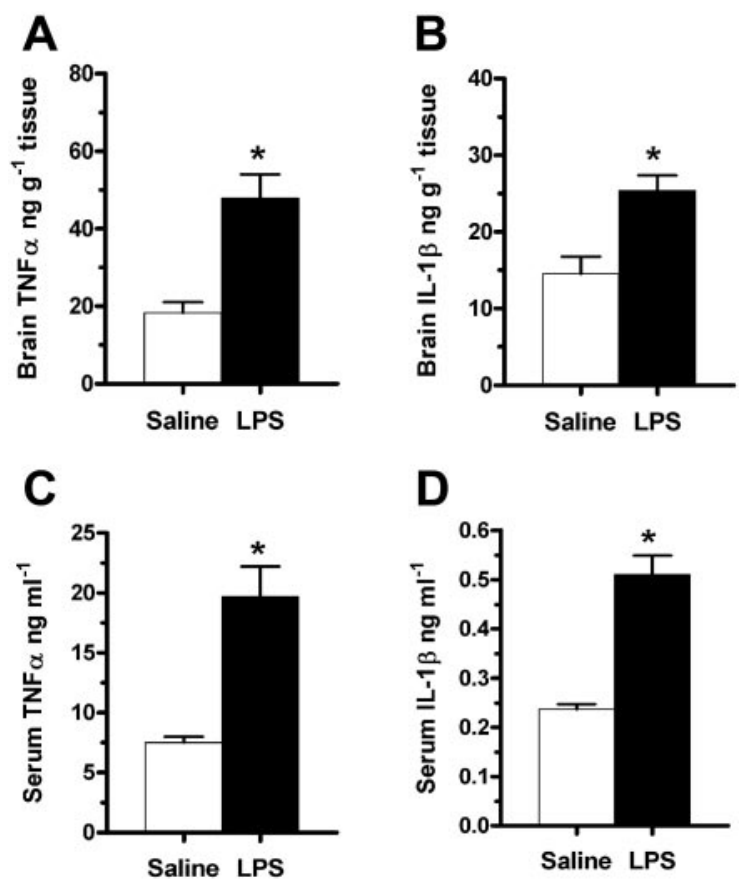

Fig. 3. Brain and serum inflammatory cytokines were elevated after ICV administration of LPS. Male FVB mice were injected with $2.5 \mu \mathrm{g}$ of LPS or $2.5 \mu \mathrm{l}$ of saline into the lateral cerebral ventricle. Levels of TNF- $\alpha$ and IL-1 $\beta$ proteins in brain $(A$ and $B)$ and serum $(C$ and $D)$ were measured $2 \mathrm{~h}$ after ICV administration of LPS or saline. Each bar represents the mean \pm SE of 4 mice. *Mean cytokine levels were higher compared with the respective saline-treated control $(P<0.05$, unpaired $t$-test $)$. 


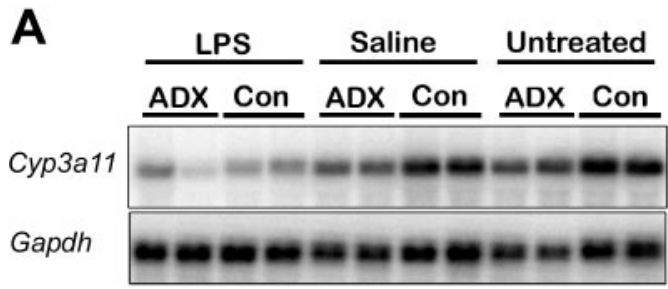

B
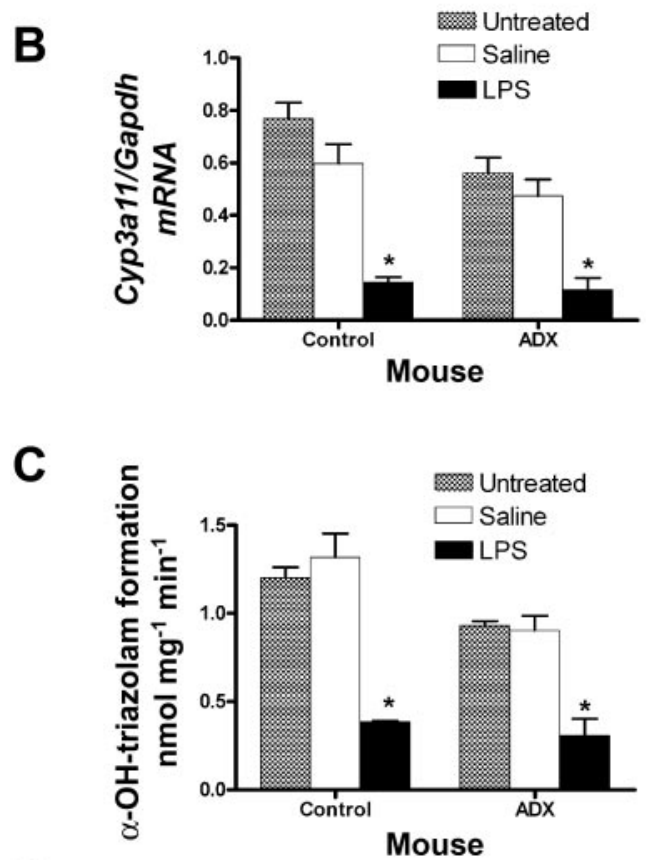

D

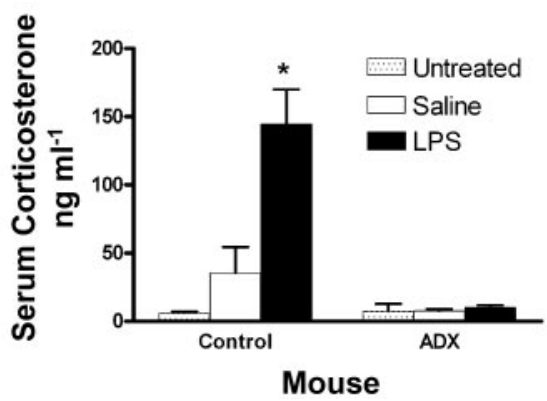

Fig. 4. Hypothalamic-adrenal-pituitary (HPA) axis does not contribute to hepatic Cyp3a11 downregulation after ICV administration of LPS. Experiment was performed 2 wk after adrenalectomy. Control (Con) mice and adrenalectomized (ADX) mice were injected with $2.5 \mu \mathrm{g}$ of LPS or $2.5 \mu \mathrm{l}$ of saline into the lateral cerebral ventricle. Analyses were performed $24 \mathrm{~h}$ after the ICV injections. A: representative Northern blots for hepatic Cyp3a11 and Gapdh. B: hepatic Cyp3a11/Gapdh expression as determined by densitometry. $C$ : hepatic Cyp3a11 activity ( $\alpha$-OH-triazolam formation). $D$ : serum corticosterone level. For the corticosterone measurement, the LPS-ADX (adrenalectomy) bar represents the average of 2 mice. All other bars represent means \pm SE of 3 or 4 mice. *Different compared with the respective saline-treated control or the untreated control $(P<0.05$, ANOVA followed by Tukey's post hoc test $)$. Statistical comparison of serum corticosterone in the ADX mice was not performed because of insufficient sample size $(n=2)$ in the LPS-ADX group.
Systemic administration of LPS mediates a reduction in hepatic Cyp3all expression and activity through TLR4 signaling. The importance of TLR4 in mediating hepatic Cyp3all downregulation after the administration of LPS by the intra-

A

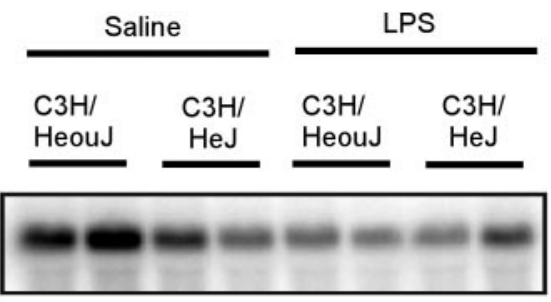

Сур3а11

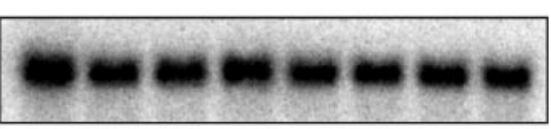

Gapdh
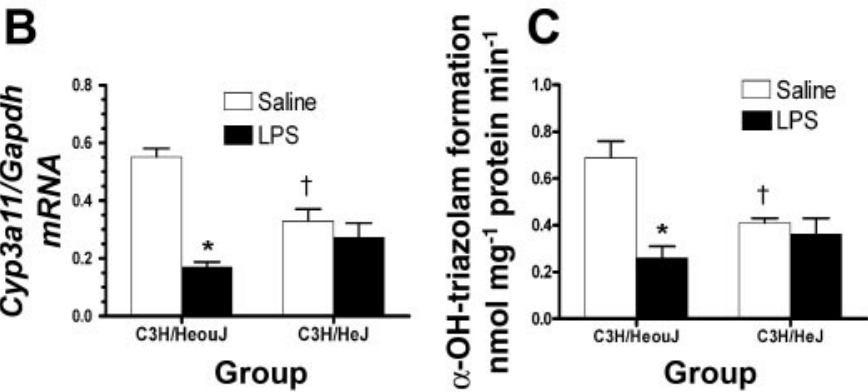

D
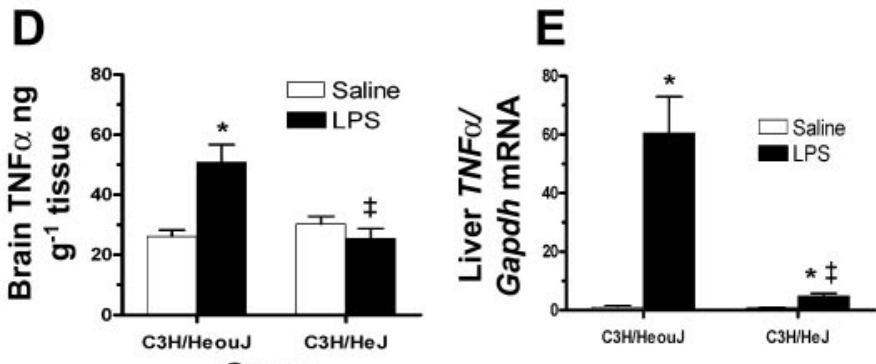

$\mathbf{F}$ Group

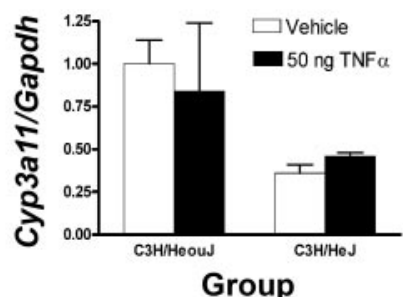

Fig. 5. Toll-like receptor-4 (TLR4) mutant mice $(\mathrm{C} 3 \mathrm{H} / \mathrm{HeJ})$ are resistant to downregulation of Cyp3a11 mRNA and activity after ICV administration of LPS. TLR4 mutant $(\mathrm{C} 3 \mathrm{H} / \mathrm{HeJ})$ and wild-type $(\mathrm{C} 3 \mathrm{H} / \mathrm{HeouJ})$ mice were injected with 2.5 $\mu \mathrm{g}$ of LPS or $2.5 \mu \mathrm{l}$ of saline into the lateral cerebral ventricle. $A$ : representative Northern blots of Cyp3all and Gapdh. B: hepatic Cyp3a11/Gapdh mRNA expression as determined by densitometry. $C$ : Cyp3all enzyme activity $(\alpha-\mathrm{OH}-$ triazolam formation) $24 \mathrm{~h}$ after treatment. $D$ : TNF- $\alpha$ protein was measured by ELISA in brain homogenates $4 \mathrm{~h}$ after ICV injection of LPS as a marker of the central nervous system (CNS) inflammatory response. $E$ : TNF- $\alpha$ mRNA was measured in liver $4 \mathrm{~h}$ after ICV injection of LPS as a marker of an inflammatory response in that organ. $F$ : effect of ICV administration of $50 \mathrm{ng}$ of TNF- $\alpha$ on hepatic Cyp3all expression. Each bar represents the mean \pm SE of 4 mice. *Different in LPS-treated compared with respective saline-treated mice $(P<0.05)$. $\dagger$ Cyp3a11 mRNA and activity were lower in saline-treated C3H/HeJ mice compared with saline-treated $\mathrm{C} 3 \mathrm{H} / \mathrm{HeouJ}$ mice, and $\$ \mathrm{TNF}-\alpha$ was lower compared with LPStreated $\mathrm{C} 3 \mathrm{H} / \mathrm{HeouJ}$ mice $(P<0.05$, ANOVA followed by Tukey's post hoc test). 
peritoneal route was examined with TLR4-expressing and TLR4 mutant mice. In $\mathrm{C} 3 \mathrm{H} / \mathrm{HeouJ}$ mice, a high dose $(5 \mathrm{mg} / \mathrm{kg})$ of LPS produced a 90\% reduction in Cyp3all mRNA and a corresponding $60 \%$ loss of $\alpha$-hydroxytriazolam formation (Fig.
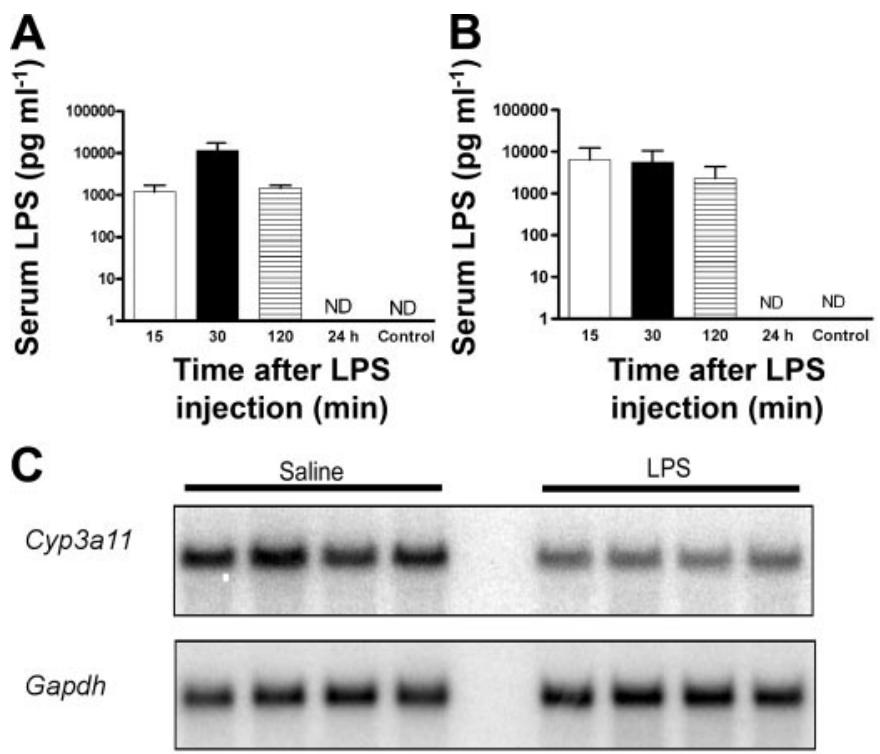

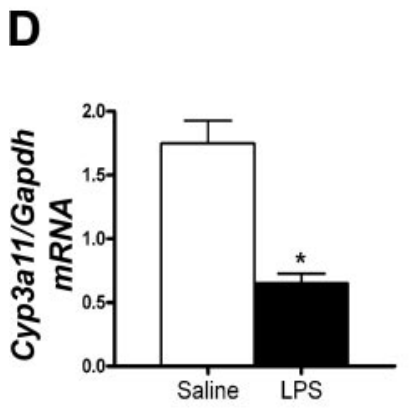

Treatment

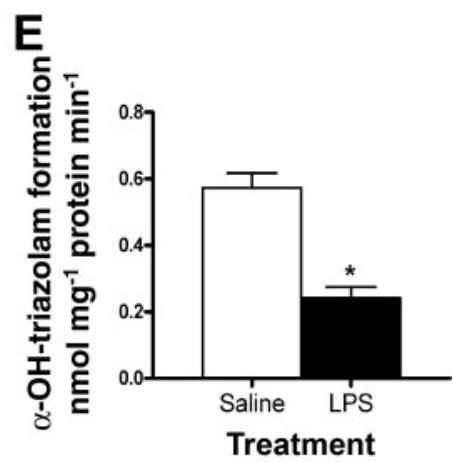

$\mathbf{F}$

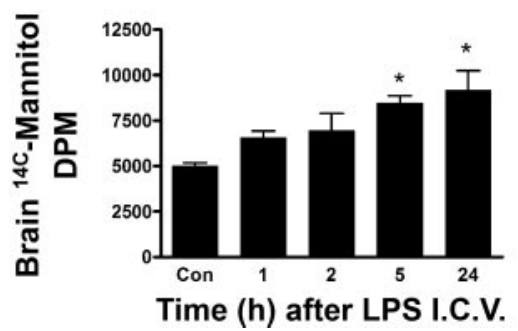

Fig. 6. After ICV administration, LPS is transferred from the brain to the periphery. Serum endotoxin levels were measured by the kinetic chromogenic Limulus ameboctye lysate assay in noninjected mice or at various times after $2.5 \mu \mathrm{g}$ of LPS were administered $\operatorname{ICV}(A)$ or intraperitoneally (IP) $(B)$ to $\mathrm{C} 3 \mathrm{H} / \mathrm{HeouJ}$ mice. ND, not determined. $C$ : Northern blots for hepatic Cyp3a11 and Gapdh mRNA. D: hepatic Cyp3al1/Gapdh mRNA expression determined by densitometry. E: hepatic microsomal Cyp3al1 activity $(\alpha-\mathrm{OH}$-triazolam formation) $24 \mathrm{~h}$ after IP administration of $2.5 \mu \mathrm{g}$ of LPS or saline to $\mathrm{C} 3 \mathrm{H} / \mathrm{HeouJ}$ mice. $F$ : brain accumulation of peripherally administered $\left[{ }^{14} \mathrm{C}\right]$ mannitol $(4 \mathrm{nmol})$ was used as marker of blood-brain solute permeability changes at various times after ICV injection of $2.5 \mu \mathrm{g}$ of LPS. Each bar represents the mean $\pm \mathrm{SE}$ of 3 or 4 mice. $D$ and $E$ : ${ }^{*} C y p 3 a 11 \mathrm{mRNA}$ or enzyme activity was lower compared with the saline-treated control $(P<0.05$, unpaired $t$-test). $F$ : ${ }^{*} P<0.05$ compared with control (ANOVA followed by Tukey's honestly significant difference test).
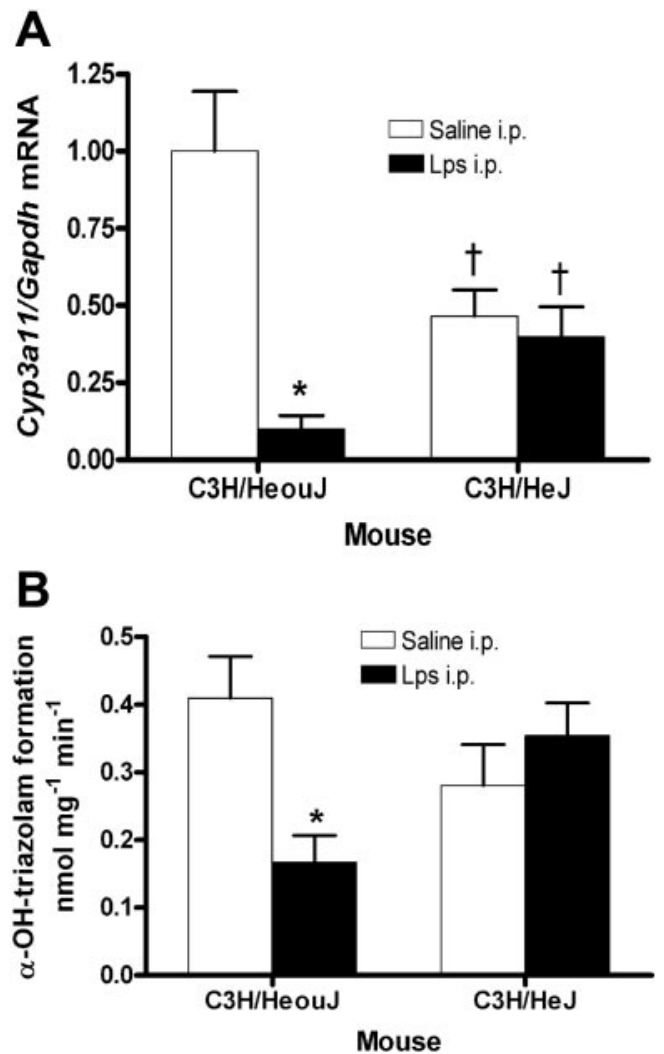

Fig. 7. Regulation of hepatic Cyp3a11 metabolism by systemic LPS is mediated via TLR4 signaling pathways. TLR4 mutant $(\mathrm{C} 3 \mathrm{H} / \mathrm{HeJ})$ and wild-type $(\mathrm{C} 3 \mathrm{H} / \mathrm{HeouJ})$ mice were injected with $125 \mu \mathrm{g}(5 \mathrm{mg} / \mathrm{kg})$ of LPS or saline into the peritoneal cavity. A: hepatic Cyp3a11/Gapdh mRNA expression as measured by densitometry. B: Cyp3all enzyme activity $24 \mathrm{~h}$ after IP injection of LPS. Each bar represents the mean \pm SE of 4 mice. *Cyp3a11 expression or activity was lower compared with the saline-treated $\mathrm{C} 3 \mathrm{H} / \mathrm{HeouJ}$ mice $(P<$ $0.05)$. $†$ Cyp3a11 expression in the $\mathrm{C} 3 \mathrm{H} / \mathrm{HeJ}$ mice was different compared with the respective saline-treated or LPS-treated $\mathrm{C} 3 \mathrm{H} / \mathrm{HeouJ}$ mice $(P<0.05$, ANOVA followed by Tukey's post hoc test).

7). In contrast, TLR4 mutant ( $\mathrm{C} 3 \mathrm{H} / \mathrm{HeJ})$ mice were completely resistant to the loss in Cyp3all mRNA and activity produced by the high dose of LPS administered intraperitoneally. These data identify that peripheral TLR4 stimulation is a requirement for the downregulation of the major drug-metabolizing hepatic cytochrome $P-450$ enzyme by systemic $E$. coli LPS.

\section{DISCUSSION}

In experimental models of CNS infection and/or inflammation, the central administration of LPS produces an inflammatory response in the brain characterized by the activation of microglia, astrocytes, and proinflammatory cytokine pathways; the release of inflammatory cytokines (TNF- $\alpha$, IL- $1 \beta$, and IL-6); and leukocyte infiltration (30,35). The CNS inflammatory response in our mouse model was confirmed by the presence of elevated inflammatory cytokines (TNF- $\alpha$ and IL$1 \beta$ ) in the brains of LPS-treated FVB or $\mathrm{C} 3 \mathrm{H} / \mathrm{HeouJ}$ mice. We have observed a significant downregulation of expression and metabolic activity of hepatic Cyp3a11 in FVB, C57BL/6, and $\mathrm{C} 3 \mathrm{H} / \mathrm{HeouJ}$ mice but not in $\mathrm{C} 3 \mathrm{H} / \mathrm{HeJ}$ mice. A large reduction in hepatic CYP3A metabolism produced by an inflammatory response would have implications for drug toxicity because the cytochrome $P-450$ subfamily metabolizes a large percentage of 


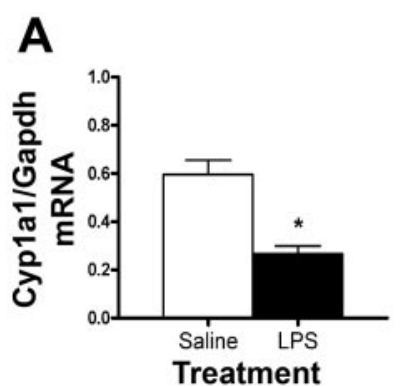

B

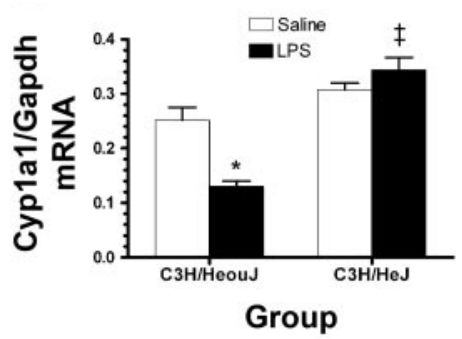

C

D
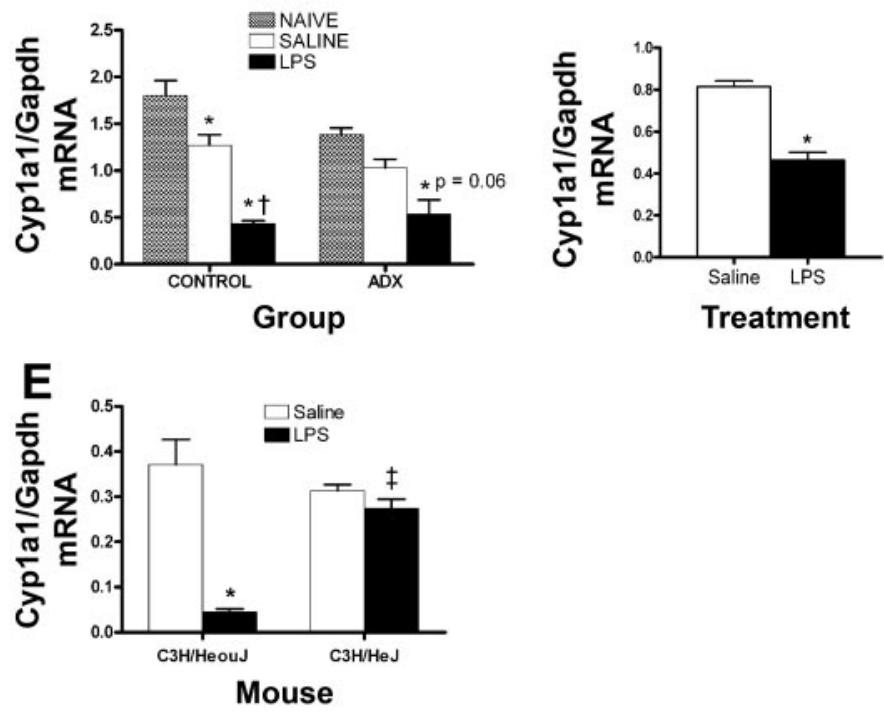

Fig. 8. Regulation of hepatic Cyplal mRNA expression by E. coli LPS. In $A-C$, mice received ICV injection of LPS $(2.5 \mu \mathrm{g})$ or saline $(2.5 \mu \mathrm{l})$. Hepatic Cyplal levels were measured $24 \mathrm{~h}$ after treatment. ICV treatment with LPS decreased hepatic Cyplal mRNA in male FVB mice $(A)$ and in TLR4expressing $(\mathrm{C} 3 \mathrm{H} / \mathrm{HeouJ})$ mice but in not TLR4 mutant $(\mathrm{C} 3 \mathrm{H} / \mathrm{HeJ})$ mice $(B)$ and in control and adrenalectomized FVB mice $(C)$ compared with relative saline controls and/or naive mice. D: hepatic Cyplal mRNA was decreased $(45 \%) 24 \mathrm{~h}$ after IP administration of LPS $(2.5 \mu \mathrm{g})$ to $\mathrm{C} 3 \mathrm{H} / \mathrm{HeouJ}$ mice compared with that in saline-injected control mice. E: hepatic Cyplal mRNA was decreased (85\%) $24 \mathrm{~h}$ after IP administration of $125 \mu \mathrm{g}$ of LPS to TLR4-expressing $(\mathrm{C} 3 \mathrm{H} / \mathrm{HeouJ})$ but not TLR4 mutant $(\mathrm{C} 3 \mathrm{H} / \mathrm{HeJ})$ mice compared with that in the respective saline controls. Each bar represents the mean $\pm \mathrm{SE}$ of 3 or 4 samples. An unpaired $t$-test was used for statistical comparison in $A$ and $D$. ANOVA was used for statistical comparison in $B, C$, and $E$. $* P<0.05$ compared with the respective saline-treated mice. $\dagger P<0.05$ compared with the respective naive mice $(C) . \ddagger P<0.05$ compared with LPS-treated $\mathrm{C} 3 \mathrm{H} / \mathrm{HeouJ}$ mice $(B$ and $E$ ). Mean $C y p 1 a 1$ mRNA level in LPS-treated adrenalectomized mice approached statistical significance compared with the saline control $(P=0.06)$.

clinically used drugs in humans (1). The present results were not restricted to Cyp3all expression as similar losses in hepatic Cyplal expression were generated by the imposed experimental conditions (Fig. 8). The extent (50-70\%) of hepatic cytochrome $P$-450 downregulation in the mouse was similar to the loss in hepatic cytochromes $P-450$ that occurred in our laboratory's previously established rat model of CNS infection/inflammation $(14,31,41)$.

The existence of a pathway to activate a peripheral acute phase response during infections of the CNS was supported by the previous observations that inflammatory cytokine levels in the periphery were elevated and the hepatic acute phase re- sponse was stimulated $(8,15,48,51)$. This undetermined signaling pathway has been proposed to regulate drug metabolism in the liver during CNS infections or inflammation (41, 45). The HPA axis is activated by cytokines during the acute phase response and may have a suppressive role against the reduction of ethoxyresorufin $O$-deethylase (Cypla), pentoxyresorufin $O$-depentylase $(C y p 2 b)$, imipramine $N$-demethylase (Cyp2d), and erythromycin $N$-demethylase $($ Cyp $3 a)$ metabolism after ICV injection of LPS to rats $(9,45,48)$. In the present study, adrenalectomy prevented the elevation of plasma corticosterone but did not protect or enhance the LPS-evoked depression in hepatic Cyp3all expression and activity after LPS administration. This confirms that the HPA axis plays no role in hepatic Cyp3all downregulation in the mouse model of CNS infection or inflammation. Others have examined the stimulation of the sympathetic nervous system or transduction of TNF- $\alpha$, IL-1 $\beta$, and IFN- $\gamma$ from the brain to the periphery, but neither of these pathways could explain the link between CNS infection/inflammation and the loss in hepatic cytochrome $P$-450 enzyme activity in rats $(31,39,45)$. Consistent with the findings of Nicholson et al. (31), in the present study, centrally administered TNF- $\alpha$ did not reduce Cyp 3 all expression in $\mathrm{C} 3 \mathrm{H} / \mathrm{HeouJ}$ or $\mathrm{C} 3 \mathrm{H} / \mathrm{HeJ}$ mice, suggesting that CNS-derived TNF- $\alpha$ is not the major factor involved in downregulation of hepatic Cyp3all after the ICV injection of LPS. IL-6 could also contribute to Cyp3al1 downregulation. However, LPS decreased hepatic Cyp3a11 expression by $80 \%$ in both IL-6-expressing and IL-6-null mice and suggested against a major role for that cytokine for the downregulation of Cyp3a11 expression by LPS (46).

LPS has been identified as a specific ligand of TLR4 $(6,36)$. Signaling through the LPS receptor (TLR4) is an additional pathway that could initiate the reduction in hepatic drug metabolism in the model of CNS inflammation. We observed that the TLR4 mutants $(\mathrm{C} 3 \mathrm{H} / \mathrm{HeJ}$ mice) were totally resistant to the LPS-mediated loss in hepatic Cyp3all expression and activity that was observed in mice that express functional TLR4. Basal levels of Cyp3a11 mRNA expression and triazolam hydroxylation were reduced in the $\mathrm{C} 3 \mathrm{H} / \mathrm{HeJ}$ mice. On the basis of those data, $\mathrm{C} 3 \mathrm{H} / \mathrm{HeJ}$ mice behaved phenotypically as slow metabolizers of triazolam, whereas $\mathrm{C} 3 \mathrm{H} / \mathrm{HeouJ}$ mice were fast metabolizers of the drug. The LPS effect in $\mathrm{C} 3 \mathrm{H} / \mathrm{HeouJ}$ mice was functionally significant because it was able to change the metabolic phenotype of the $\mathrm{C} 3 \mathrm{H} / \mathrm{HeouJ}$ mice from that of a fast metabolizer to that of a slow metabolizer of triazolam. Several of our findings also support that $\mathrm{C} 3 \mathrm{H} / \mathrm{HeJ}$ mice are resistant to LPS-mediated reductions in Cyp3all expression and activity because of inhibition of signal transduction through the TLR4 and not because of reduced basal expression of that cytochrome $P-450$ gene. First, it was clear from the peripheral inflammation study that LPS could reduce Cyp3a11 mRNA and triazolam hydroxylation in $\mathrm{C} 3 \mathrm{H} / \mathrm{HeouJ}$ mice below basal levels in the $\mathrm{C} 3 \mathrm{H} / \mathrm{HeJ}$ mice. Second, basal Cyplal expression was similar in $\mathrm{C} 3 \mathrm{H} / \mathrm{HeouJ}$ and $\mathrm{C} 3 \mathrm{H} / \mathrm{HeJ}$ (Fig. 8) mice but was only depressed by LPS in the $\mathrm{C} 3 \mathrm{H} / \mathrm{HeouJ}$ mice. Finally, hyporesponsiveness to LPS in the TLR4-mutant mice was confirmed by the lack of a TNF- $\alpha$ response in the brain and liver.

The lack of the TNF- $\alpha$ response in $\mathrm{C} 3 \mathrm{H} / \mathrm{HeJ}$ mice after the ICV administration of LPS indicated the absence of a CNS inflammatory response. However, we could not conclude that 
blockade of the CNS inflammatory response was the only factor that protected the TLR4 mutant mice from the loss in hepatic Cyp3al1 because TLR4 are also present on peripheral macrophages and hepatocytes and could still elicit an immune response to $E$. coli $\operatorname{LPS}(4,21)$. This idea of a peripheral inflammatory response is supported by the observation that liver TNF- $\alpha$ mRNA and serum levels of TNF- $\alpha$ and IL-1 $\beta$ were elevated by ICV administered LPS. If LPS was secreted into the blood from the cerebral spinal fluid, then a resulting peripheral inflammatory response could explain the decrease in hepatic Cyp3all metabolism.

Several studies have suggested that LPS was restricted to the CNS when it was injected into the lateral ventricle of the brain $(41,45)$. In contrast, the present observations provide convincing evidence that LPS is not restricted to the CNS after central administration and is transferred to the blood in significant quantities. Similar quantities of LPS were detected in serum, and a similar loss in hepatic Cyp3all expression and activity was observed after the intraperitoneal administration of LPS $(2.5 \mu \mathrm{g})$. The systemic bioavailability, as approximated by AUC, was similar after both routes of administration. These results indicated that, after ICV administration, the amount of LPS reaching the systemic circulation is large enough to alter hepatic cytochrome $P-450$ solely by actions in peripheral tissues. Thus a transfer of LPS from the CNS may have lead to the previous observation of reduced hepatic cytochrome $P-450$ after ICV administration of LPS to rats $(41,45)$.

E. coli LPS (0127:B8, $200 \mu \mathrm{g})$ injected ICV to rats increased blood-brain barrier permeability between 4 and $16 \mathrm{~h}$ after the injection (18). Changes in blood-brain barrier permeability could result in LPS leakage into the peripheral circulation. However, our experimental results suggested that peak LPS transfer (between 1 and $2 \mathrm{~h}$ ) from the ventricles occurred on a time scale that preceded the opening of the blood-brain barrier. The majority of cerebral spinal fluid is resorbed by bulk flow into the systemic circulation via transfer from the subarchnoid villi into the superior sagittal venous sinus (7). The bulk flow mechanism begins to return other blood-brain barrier-impermeable substances (albumin and leptin) to the systemic circulation within minutes of their injection by the ICV route (7, 24). Thus the bulk flow reabsorption of cerebral spinal fluid is likely the more important mechanism for LPS transfer to the peripheral circulation as opposed to passage across the bloodbrain barrier.

The decrease in hepatic Cyp3all expression and activity in response to circulating levels of LPS also appears to involve TLR4, as the intraperitoneal injection of LPS had no effect in TLR4-mutant mice. Others have shown that $\mathrm{C} 3 \mathrm{H} / \mathrm{HeJ}$ mice were resistant to LPS downregulation of hepatic ethoxycoumarin dealkylase (Cyp2a) and ethoxyresorufin dealkylase (Cypla/2) enzyme activities $24 \mathrm{~h}$ after LPS was administered intraperitoneally, but this work was conducted before the identification of TLR4 as a critical component of the LPS signal transduction pathway $(13,44)$. Also, in a model of indomethacin-induced intestinal injury, TLR4 activation by LPS released from intestinal flora may contribute to downregulation of hepatic Cyp3a11, Cypla1/2, and Cyp2d9 enzyme activities (25). Together, these results directly support the idea that peripheral TLR4 are involved in the regulation of hepatic cytochrome $P-450$ enzymes by peripherally administered LPS. TLR4-mediated signaling occurs through two intracellular

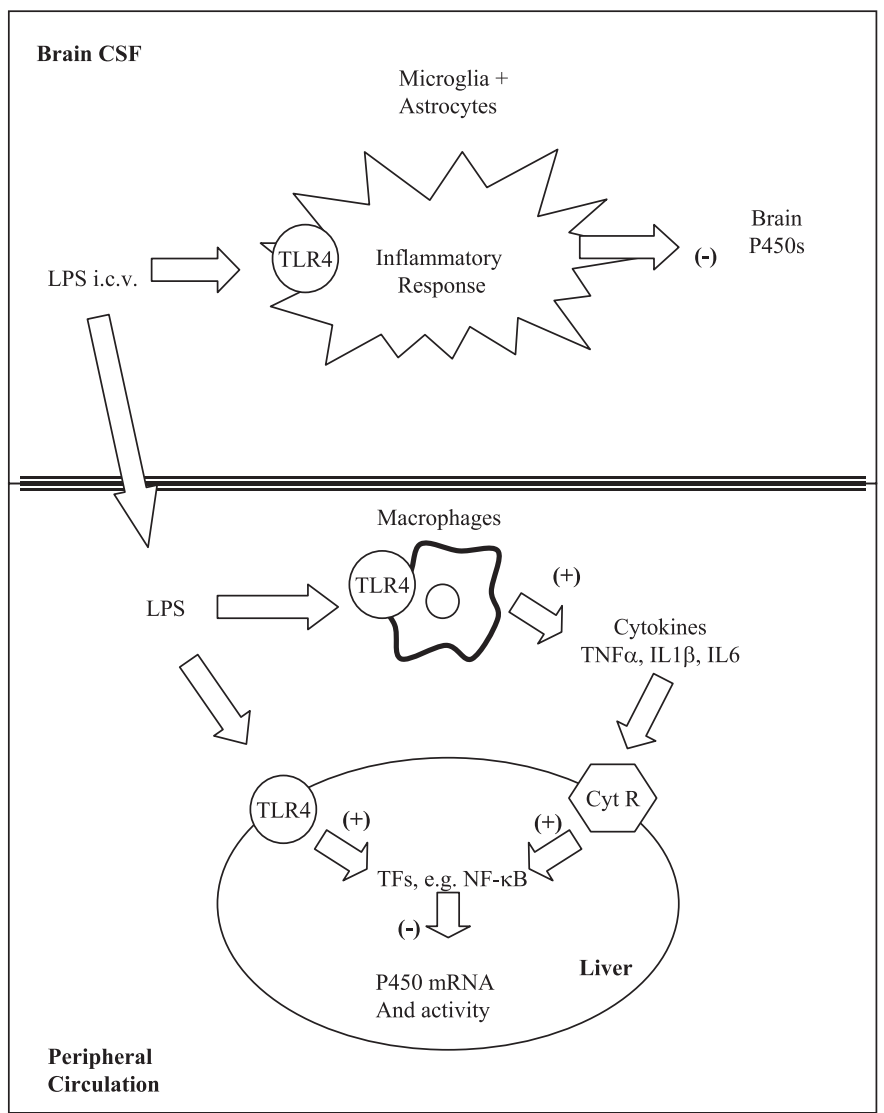

Fig. 9. Downregulating hepatic cytochrome $P-450$ metabolism in a model of gram-negative bacterial infection of the CNS. LPS injected within the lateral ventricle produces TLR4-dependent CNS inflammation, which may be important for decreased cytochrome $P-450$ activity in the brain but is not likely the major factor that reduces hepatic cytochrome $P-450$ metabolism. We demonstrate an alternative mechanism in which centrally administered LPS is rapidly transferred from the cerebral spinal fluid (CSF) to the blood. Peripheral LPS activates TLR4-dependent inflammatory pathways in peripheral immune cells (e.g., macrophages), leading to an elevation in circulating inflammatory cytokines (e.g., TNF- $\alpha$, IL-1 $\beta$, and IL-6). It is well known that those inflammatory cytokines activate signal transduction pathways within the hepatocyte and the expression/activation hepatic transcription factors (e.g., NF-кB), which inhibit expression of cytochrome $P-450$. Additionally, direct LPS stimulation of TLR4 signaling pathways in the hepatocyte represents a potential pathway that could trigger intracellular events that lead to Cyp3a11 downregulation. TF, transcription factor; Cyt R, cytokine receptor; +, activation; - , inhibition or downregulation.

pathways (47). The MyD88-dependent pathway results in the direct induction of inflammatory cytokines (e.g., TNF, IL-1 $\beta$, and IL-6). The MyD88-independent pathway activates NF-кB with delayed kinetics as well as the interferon response factor-3, which upregulates the expression of interferon-inducible genes. Although not determined in the present study, experiments in MyD88-deficient and interferon response factor-3deficient mice should reveal which of these two pathways is most important for Cyp3al1 downregulation by LPS.

Our findings have led to a putative model of how CNS infection could lead to the loss of cytochrome $P-450$ expression and activity in the liver, as shown in Fig. 9. LPS injected within the lateral ventricle produces TLR4-dependent CNS inflammation. The localized inflammation is likely important for the loss in cytochrome $P-450$ that occurs in the brain (41) but is not the major factor that depresses cytochrome $P-450$ 
metabolism in the liver. We propose that centrally administered LPS is rapidly transferred from the cerebral spinal fluid to the blood. Through a TLR4-dependent mechanism, circulating LPS then reduces hepatic Cyp3all mRNA expression and enzyme activity. The loss of hepatic cytochrome $P-450$ produced by systemic LPS could occur indirectly through the action of circulating cytokines such as TNF- $\alpha$, IL-1 $\beta$, and IL-6 that are released from a peripheral source (e.g., macrophages or Kupffer cells) $(12,13,28,31,39,44)$. Those cytokines activate nuclear transcription factors within the hepatocyte, which regulate cytochrome $P$-450 expression in the liver $(2,3,17,19$, $29,33,38)$. Despite the direct link between cytokines and cytochrome $P-450$ expression, large doses of LPS $(1-5 \mathrm{mg} / \mathrm{kg}$ ) were able to mediate hepatic Cyp3all downregulation in vivo in mice with targeted disruptions in IL- 6 and the TNF- $\alpha$ receptor $(46,50)$. This could be explained by the observations that LPS stimulates NF-кB signaling in isolated hepatocytes through TLR4 present on those cells $(21,49)$. Thus the direct action of LPS on the hepatocyte represents a potential mechanism for Cyp3all downregulation in the liver.

In summary, in the presence of a CNS infection, the transfer of endotoxin from the brain to the periphery could stimulate a peripheral immune response that produces a loss in cytochrome $P$-450-mediated drug metabolism in the liver. We have also identified that stimulation of TLR4 is responsible for linking the immune response to $E$. coli endotoxin with a major drug metabolizing cytochrome $P-450$ in the mouse liver. The reduction in cytochrome $P-450$ enzymes during inflammatory responses or infections of the CNS may reduce the metabolism and elimination of several clinically used drugs and increase the potential for adverse drug interactions.

\section{ACKNOWLEDGMENTS}

We thank Dr. Jean Marshall and Yi-song Wei (Department of Immunology, Dalhousie University) for performing the cytokine assays.

\section{GRANTS}

This work was supported by the Canadian Institutes of Health Research and the Nova Scotia Health Research Foundation. K. B. Goralski was supported by postdoctoral fellowships from the Nova Scotia Health Research Foundation, the IWK Health Centre, The Canadian Institutes of Health Research, and the Reynolds' Foundation. D. Abdulla was a recipient of an Eliza Ritchie Scholarship.

\section{REFERENCES}

1. Anzenbacher P and Anzenbacherova E. Cytochromes P450 and metabolism of xenobiotics. Cell Mol Life Sci 58: 737-747, 2001.

2. Baumann $\mathbf{H}$ and Gauldie $\mathbf{J}$. The acute phase response. Immunol Today 15: 74-80, 1994.

3. Beigneux AP, Moser AH, Shigenaga JK, Grunfeld C, and Feingold KR. Reduction in cytochrome P-450 enzyme expression is associated with repression of CAR (constitutive androstane receptor) and PXR (pregnane $\mathrm{X}$ receptor) in mouse liver during the acute phase response. Biochem Biophys Res Commun 293: 145-149, 2002.

4. Beutler B, Hoebe K, Du X, and Ulevitch RJ. How we detect microbes and respond to them: the Toll-like receptors and their transducers. J Leukoc Biol 74: 479-485, 2003.

5. Chang GW and Kam PC. The physiological and pharmacological roles of cytochrome P450 isoenzymes. Anaesthesia 54: 42-50, 1999.

6. Chow JC, Young DW, Golenbock DT, Christ WJ, and Gusovsky F. Toll-like receptor-4 mediates lipopolysaccharide-induced signal transduction. J Biol Chem 274: 10689-10692, 1999.

7. Davson H, Welch K, and Segal MB. Physiology and Pathophysiology of the Cerebrospinal Fluid. Edinburgh: Churchill Livingstone, 1987.

8. De Simoni MG, Del Bo R, De Luigi A, Simard S, and Forloni G. Central endotoxin induces different patterns of interleukin (IL)-1 $\beta$ and
IL-6 messenger ribonucleic acid expression and IL-6 secretion in the brain and periphery. Endocrinology 136: 897-902, 1995.

9. Del Rey A and Besedovsky HO. Metabolic and neuroendocrine effects of pro-inflammatory cytokines. Eur J Clin Invest 22, Suppl 1: 10-15, 1992.

10. El-Masry S-D, Cohen GM, and Mannering GJ. Sex-dependent differences in drug metabolism in the rat. I. Temporal changes in microsomal drug-metabolizing system of the liver during sexual maturation. Drug Metab Dispos 2: 267-278, 1974.

11. Franklin KBJ and Paxinos G. The Mouse Brain in Stereotaxic Coordinates. San Diego: Academic, 1997.

12. Ghezzi P, Saccardo B, and Bianchi M. Recombinant tumor necrosis factor depresses cytochrome P450-dependent microsomal drug metabolism in mice. Biochem Biophys Res Commun 136: 316-321, 1986.

13. Ghezzi P, Saccardo B, Villa P, Rossi V, Bianchi M, and Dinarello CA. Role of interleukin-1 in the depression of liver drug metabolism by endotoxin. Infect Immun 54: 837-840, 1986.

14. Goralski KB, Hartmann G, Piquette-Miller M, and Renton KW. Downregulation of mdrla expression in the brain and liver during CNS inflammation alters the in vivo disposition of digoxin. Br J Pharmacol 139: 35-48, 2003.

15. Gottschall PE, Komaki G, and Arimura A. Increased circulating interleukin-1 and interleukin-6 after intracerebroventricular injection of lipopolysaccharide. Neuroendocrinology 56: 935-938, 1992.

16. Hardy KW and White TD. Some commercial preparations of Escherichia coli bacterial endotoxin lipopolysaccharide (LPS) are contaminated with biologically active substances. J Neurochem 78: 1183-1184, 2001.

17. Iber H, Chen Q, Cheng PY, and Morgan ET. Suppression of CYP2C11 gene transcription by interleukin-1 mediated by NF- $\mathrm{B}$ binding at the transcription start site. Arch Biochem Biophys 377: 187-194, 2000.

18. Jaworowicz DJ Jr, Korytko PJ, Singh Lakhman S, and Boje KM. Nitric oxide and prostaglandin E2 formation parallels blood-brain barrier disruption in an experimental rat model of bacterial meningitis. Brain Res Bull 46: 541-546, 1998.

19. Jover R, Bort R, Gomez-Lechon MJ, and Castell JV. Down-regulation of human CYP3A4 by the inflammatory signal interleukin-6: molecular mechanism and transcription factors involved. FASEB J 16: 1799-1801, 2002.

20. Laflamme $\mathbf{N}$ and Rivest $\mathbf{S}$. Toll-like receptor 4: the missing link of the cerebral innate immune response triggered by circulating gram-negative bacterial cell wall components. FASEB J 15: 155-163, 2001.

21. Liu S, Gallo DJ, Green AM, Williams DL, Gong X, Shapiro RA, Gambotto AA, Humphris EL, Vodovotz Y, and Billiar TR. Role of toll-like receptors in changes in gene expression and NF- $\mathrm{KB}$ activation in mouse hepatocytes stimulated with lipopolysaccharide. Infect Immun 70: 3433-3442, 2002.

22. Livak KJ and Schmittgen TD. Analysis of relative gene expression data using real-time quantitative PCR and the 2- $\Delta \Delta \mathrm{C}(\mathrm{T})$ method. Methods 25: 402-408, 2001.

23. Lowry OH, Rosebrough NJ, Farr AL, and Randall RJ. Protein measurement with the Folin phenol reagent. J Biol Chem 193: 265-275, 1951.

24. Maness LM, Kastin AJ, Farrell CL, and Banks WA. Fate of leptin after intracerebroventricular injection into the mouse brain. Endocrinology 139: 4556-4562, 1998

25. Masubuchi $\mathbf{Y}$ and Horie T. Resistance to indomethacin-induced downregulation of hepatic cytochrome P450 enzymes in the mice with nonfunctional Toll-like receptor 4. J Hepatol 39: 349-356, 2003.

26. McCurdy JD, Lin TJ, and Marshall JS. Toll-like receptor 4-mediated activation of murine mast cells. J Leukoc Biol 70: 977-984, 2001.

27. Monshouwer M, Agnello D, Ghezzi P, and Villa P. Decrease in brain cytochrome P450 enzyme activities during infection and inflammation of the central nervous system. Neuroimmunomodulation 8: 142-147, 2000.

28. Morgan ET. Regulation of cytochrome $\mathrm{p} 450$ by inflammatory mediators: why and how? Drug Metab Dispos 29: 207-212, 2001.

29. Morgan ET, Li-Masters T, and Cheng PY. Mechanisms of cytochrome P450 regulation by inflammatory mediators. Toxicology 181-182: 207210, 2002.

30. Nadeau $\mathbf{S}$ and Rivest $\mathbf{S}$. Endotoxemia prevents the cerebral inflammatory wave induced by intraparenchymal lipopolysaccharide injection: role of glucocorticoids and CD14. J Immunol 169: 3370-3381, 2002.

31. Nicholson TE and Renton KW. Role of cytokines in the lipopolysaccharide-evoked depression of cytochrome P450 in the brain and liver. Biochem Pharmacol 62: 1709-1717, 2001. 
32. Pan J, Xiang Q, Ball S, Scatina J, Kao J, and Hong JY. Lipopolysaccharide-mediated modulation of cytochromes P450 in Stat 1 null mice. Drug Metab Dispos 31: 392-397, 2003.

33. Pascussi JM, Gerbal-Chaloin S, Pichard-Garcia L, Daujat M, Fabre JM, Maurel P, and Vilarem MJ. Interleukin-6 negatively regulates the expression of pregnane $\mathrm{X}$ receptor and constitutively activated receptor in primary human hepatocytes. Biochem Biophys Res Commun 274: 707713, 2000.

34. Perloff MD, von Moltke LL, Court MH, Kotegawa T, Shader RI, and Greenblatt DJ. Midazolam and triazolam biotransformation in mouse and human liver microsomes: relative contribution of CYP3A and CYP2C isoforms. J Pharmacol Exp Ther 292: 618-628, 2000.

35. Perry VH, Andersson PB, and Gordon S. Macrophages and inflammation in the central nervous system. Trends Neurosci 16: 268-273, 1993.

36. Poltorak A, He X, Smirnova I, Liu MY, Van Huffel C, Du X, Birdwell D, Alejos E, Silva M, Galanos C, Freudenberg M, Ricciardi-Castagnoli P, Layton B, and Beutler B. Defective LPS signaling in $\mathrm{C} 3 \mathrm{H} / \mathrm{HeJ}$ and C57BL/10ScCr mice: mutations in Tlr4 gene. Science 282: 20852088, 1998.

37. Qureshi ST, Lariviere L, Leveque G, Clermont S, Moore KJ, Gros P, and Malo D. Endotoxin-tolerant mice have mutations in Toll-like receptor 4 (Tlr4). J Exp Med 189: 615-625, 1999.

38. Ramadori G and Christ B. Cytokines and the hepatic acute-phase response. Semin Liver Dis 19: 141-155, 1999.

39. Renton KW. Alteration of drug biotransformation and elimination during infection and inflammation. Pharmacol Ther 92: 147-163, 2001.

40. Renton KW, Dibb S, and Levatte TL. Lipopolysaccharide evokes the modulation of brain cytochrome P4501A in the rat. Brain Res 842: 139-147, 1999.

41. Renton KW and Nicholson TE. Hepatic and central nervous system cytochrome P450 are down-regulated during lipopolysaccharide-evoked localized inflammation in brain. J Pharmacol Exp Ther 294: 524-530, 2000.
42. Scheld WM, Koedel U, Nathan B, and Pfister HW. Pathophysiology of bacterial meningitis: mechanism(s) of neuronal injury. J Infect Dis 186, Suppl 2: S225-233, 2002.

43. Sewer MB, Barclay TB, and Morgan ET. Down-regulation of cytochrome P450 mRNAs and proteins in mice lacking a functional NOS2 gene. Mol Pharmacol 54: 273-279, 1998.

44. Shedlofsky SI, Swim AT, Robinson JM, Gallicchio VS, Cohen DA, and McClain CJ. Interleukin-1 (IL-1) depresses cytochrome P450 levels and activities in mice. Life Sci 40: 2331-2336, 1987.

45. Shimamoto Y, Kitamura H, Iwai M, Saito M, Kazusaka A, and Fujita S. Mechanism of decrease in levels of hepatic P450 isozymes induced by intracerebral endotoxin: independence from sympathetic nervous and adrenocortical systems. Arch Toxicol 73: 41-49, 1999.

46. Siewert E, Bort R, Kluge R, Heinrich PC, Castell J, and Jover R. Hepatic cytochrome P450 down-regulation during aseptic inflammation in the mouse is interleukin 6 dependent. Hepatology 32: 49-55, 2000.

47. Takeda K and Akira S. TLR signaling pathways. Semin Immunol 16: 3-9, 2004.

48. Terrazzino S, Perego C, De Luigi A, and De Simoni MG. Interleukin-6, tumor necrosis factor and corticosterone induction by central lipopolysaccharide in aged rats. Life Sci 61: 695-701, 1997.

49. Wang X, Li W, Lu J, Li N, and Li J. Lipopolysaccharide suppresses albumin expression by activating NF- $\mathrm{B}$ in rat hepatocytes. $J$ Surg Res 122: 274-279, 2004.

50. Warren GW, Poloyac SM, Gary DS, Mattson MP, and Blouin RA. Hepatic cytochrome $P$-450 expression in tumor necrosis factor-alpha receptor (p55/p75) knockout mice after endotoxin administration. $J$ Pharmacol Exp Ther 288: 945-950, 1999.

51. Wilcockson DC, Campbell SJ, Anthony DC, and Perry VH. The systemic and local acute phase response following acute brain injury. J Cereb Blood Flow Metab 22: 318-326, 2002. 